part found free in the fluid, the epithelium being studded with other bacterial forms.

Persons who have not been in the habit of examining dried saliva-films will probably be surprised at the number and variety of the organisms which are, more or less, constantly to be found in the mouth; and especially at the number of spirilla with which the fluid is generally crowded.

The alvine discharges in cholera sometimes swarm with precisely similar spiral organisms, and, indeed, as has long been known, the fluid exuded into the intestines in this disease is peculiarly suitable for the growth of these and allied microbes. But, so far as my own experiencedating from 1869 - of the microscopic examination of such a fluid goes, all the microphytes ordinarily found in it are likewise to be found, to a greater or less extent, in the secretions of the mouth and fauces of unaffected persons. And with reference to the comma-like Bacilli found in cholera, to which such virulent properties have been ascribed, I shall continue to regard them as identical in their nature with those ordinarily present in the saliva until it has been clearly demonstrated that they are physiodogically different.

Pathological Laboratory, Netley, September I

\section{FORESTS IN COBURG, GERMANY, AND RUSSIA}

A BLUE-BOOK under the title of "Reports by Her A Majesty's Representatives abroad on the Cultivation of Woods and Forests in the Countries in which they reside," has just been published by Messrs. Harrison \& Sons. These Reports are of an extremely interesting character, and we gladly draw attention to them, appearing as they do at an opportune moment before the close of the Forestry Exhibition at Edinburgh.

The Reports come from Coburg and Gotha, Germany, Norway, Russia, and Sweden, and in the form of an appendix is a précis by Dr. Lyons, M.P., of the Reports on Forestry of the United States Department of Agriculture. In each one of these Reports much valuable information is given and information of a very varied character. Thus in the first we are told that the forests in Gotha consist of 85 per cent. of pine and 15 per cent. of other wood. The principal timber-trees are pine and beech, whereas the remaining sorts of wood, namely Scotch fir, spruce, larch, oak, maple, ash, birch, and elm are found only in small quantities or mixed with the other species. The period during which the different woods are gradually brought into use is such that pine forests and mixed forests shall yield as large an amount as possible of saleable timber, whilst in the beech woods the greatest amount of wood as fuel is sought without allowing the trees to attain an age at which they would no longer pay the interest on the value of the soil. Pine and beech wood in higher situations are, according to these principles, usually cultivated and worked in cycles of one hundred years, while spruce on the lower heights and in the plains are worked on an eighty ycars' cycle. The woods for protection on the high grounds are subject to especial treatment, as no clear fellings take place, and care is taken to leave standing groups of foliage trees equally distributed over the whole surface. The usual rules followed are : early felling of the trees in a cycle of eighty years, leaving occasional large shelter trees, and utilising the undergrowth for purposes of renewal. The administration of the Domain forests in the Duchy of Coburg is carried on on scientific principles, and consists of regular felling at stated periods over certain areas; pine timber trees are usually cut every ninety years, while oak, ash, beech, birch, \&c., are not cut till after 120 years' growth.

The Report on the general administration of Prussian
State Forests treats of their organisation, expenditure, and results, and points to the desirability of introducing others than indigenous trees into the forests. On the subject of education in forestry it is stated that the School of Forestry at Eberswalde completed in June I 880 the fiftieth year of its existence, and had at that period in all nearly 1600 pupils. There is also a School of Forestry at Münden, and the half-yearly attendance at both schools showed in 1878 an average of 148 pupils, whereas in 1880 the number had increased to 210 . The attendance was therefore largely on the increase, and it was then proposed to give voluntary education in these matters to the "Jäger Bataillonen" of the army. This plan has, according to latest accounts, been attended with so much success that the education has become obligatory, and forms a regular portion of their service.

From Russia a very elaborate Report treats, amongst other things, of the various kinds of trees found in Russia, with notes on their distribution, and some interesting facts on the consumption of wood and the uses to which it is put, showing that house and ship building consume a very large proportion, and that the minor industrics when put together form a not unimportant total. After showing the extensive destruction of forests that has been going on in different parts of Russia for some years past, the Report considers the question of plantations along railways, the object of which is to protect the track from snowdrifts, and a list of the best trees and shrubs for this purpose is given. (n the subject of tree-planting on the steppes of South Russia, it is stated that Count Kisseleff, when travelling through several provinces in I840 found, much to his surprise, amongst the German colonists not only good kitchen gardens but also flourishing plantations of forest trees. The colonists had been obliged on every plot of land to plant a certain number of trees. The first experiences, however, were so severe that many of the colonists preferred to return to Germany ; those that remained were forced to plant their allotments with trees which, with infinite trouble, they succeeded in doing, and these plantations are now a great ornament to the steppes, and from a climatic as well as an agricultural point of view have been of great importance to the colonists, and have laid the foundation of the planting which is now carried out on the steppes in a scientific manner. A forestry school was established, but closed in 1866 , and the allowances for planting which had been granted were reduced to a minimum. Since that, however, matters have been put on a more satisfactory footing, and planting is conducted in a systematic manner.

\section{STONE HATCHETS IN CHINA}

ITTLE has yet been done to illustrate the Stone Age $\mathrm{L}$ in China, and this is very likely to be true for some time to come from the fact that the pcople of the country worked in metals four thousand years ago.

To begin with the Han dynasty, B.C. 206 to A.D. 220 , one chief source of revenue was iron in those days, and Shansi had grown rich and powerful because of her iron foundries. The correct Confucianists objected to the spirit of gain-seeking which they saw showing itself in the expansion of trade. In the reign of Chauti, B.c. 8o, a book was written on the salt and iron duties, which was a record of the views then maintained by the purists of the Confucian school in contrast with those of the political economists of that day. The advantages of the encouragement of trade were detailed in full, and the sympathy of the modern reader goes with the economists, who saw that the strength and prosperity of the country must be increased by developing her resources. The country was then old, and the stone hatchet period must be sought much earlier. The same state of things existed in the time of Kwan chung, B.C. 700 . Living before Confucius, 